The University of San Francisco

USF Scholarship: a digital repository @ Gleeson Library | Geschke Center

Nursing and Health Professions Faculty Research and Publications

2009

\title{
Can International Law Secure Women's Health? An Examination of CEDAW and its Optional Protocol
}

Dhrubajyoti Bhattacharya

University of San Francisco, dbhattacharya@usfca.edu

Follow this and additional works at: http://repository.usfca.edu/nursing_fac

Part of the International Law Commons, and the Women's Health Commons

\section{Recommended Citation}

Proceedings of the Annual Meeting (American Society of International Law), Vol. 103, (March 25-28, 2009), pp. 471-473

This Article is brought to you for free and open access by the School of Nursing and Health Professions at USF Scholarship: a digital repository @ Gleeson Library | Geschke Center. It has been accepted for inclusion in Nursing and Health Professions Faculty Research and Publications by an authorized administrator of USF Scholarship: a digital repository @ Gleeson Library | Geschke Center. For more information, please contact repository@usfca.edu. 
the costs that could ensue for citizens of the Union and to set them against the advantages ... ., 5 We submit that this position is not convincing from an economic perspective and show that a system endorsing a no-fault liability rule may have unreasonably high administrative costs.

\title{
CONCLUSION
}

Unlike some commentators criticizing the European courts, we conclude that their approach has a sound economic rationale. An important caveat applies to our analysis: we did not attempt to shed light on issues of equity. However, we submit that equity gaps are better addressed through risk insurance policies or alternative compensation mechanisms.

\section{Can International Law Secure Women's Health? an Examination of CEDAW and its Optional Protocol}

\author{
By Dhrubajyoti Bhattacharya*
}

\section{INTRODUCTION}

The year 2009 marks the thirtieth anniversary of the Convention on the Elimination of All Forms of Discrimination Against Women ("CEDAW'). ${ }^{1}$ CEDAW is unique among international agreements in carving out a healthcare provision exclusively for women. Under CEDAW's Optional Protocol ("Protocol'), the CEDAW Committee retains exclusive jurisdiction to consider claims brought by individuals against a state party. ${ }^{2}$ Although decisions are not legally binding, the Committee engages in a quasi-legal analysis by applying CEDAW to the relevant facts and articulating precise governmental violations and obligations.

I conducted a comprehensive analysis of all ten decisions issued thus far under the Protocol. I argue that the legal analyses have been unsound and compromised the integrity of the interpretive process. An enhanced framework is proposed to address a number of pressing and emerging women's health issues.

The research addresses three broad questions. First, do CEDAW and the Protocol afford more robust substantive and procedural safeguards to secure women's health? Second, has the CEDAW Committee interpreted the treaty in an objective and consistent manner? Third, what challenges exist to address pressing and emerging women's health issues under CEDAW?

\section{Normative Framework: CEDAW, Protocol, and Rules of Procedure}

As a normative framework, CEDAW, its Protocol, and the Committee's Rules of Procedure together afford substantive and procedural safeguards to address health-related individual-

\footnotetext{
${ }^{5}$ FIAMM, 2008 E.C.R. I-6513.

* Assistant Professor, Health Law and Policy, Southern Illinois University School of Medicine; Assistant Professor, Medical Jurisprudence, Southern Illinois University School of Law.

${ }^{1}$ Convention on the Elimination of All Forms of Discrimination Against Women ("CEDAW'), G.A. Res. 34/ 180, Annex, U.N. Doc. A/RES/34/46/Annex (Dec. 18, 1979).

${ }^{2}$ Optional Protocol to the Convention on the Elimination of All Forms of Discrimination Against Women ("Protocol"), U.N. Doc. A/54/49 (Oct. 15, 1999).
} 
and population-based claims. The healthcare provision is found in Article 12 of CEDAW, which provides that:

1. States Parties shall take all appropriate measures to eliminate discrimination against women in the field of health care in order to ensure, on a basis of equality of men and women, access to health care services, including those related to family planning.

2. Notwithstanding the provisions of paragraph 1 of this article, States Parties shall ensure to women appropriate services in connection with pregnancy, confinement and the post-natal period, granting free services where necessary, as well as adequate nutrition during pregnancy and lactation.

Article 12(1) retains elements of formal equality, whereby men and women are afforded the same rights, conditions, and opportunities. A number of issues, however, remain unresolved. Socioeconomic status, spousal consent for seeking care, or the availability of female physicians, are examples of access barriers to care. There is no universal model for allocating resources to address disparities and the social determinants of health. Moreover, interpretation is vital to address emerging issues as a result of technological advancements. For example, is emergency contraception "related to" family planning?

Article 12(2) retains elements of substantive equality. Recognizing that formal equality may inadvertently create or sustain disparities, the provision requires positive programs exclusively for women. A pressing issue that must be addressed is whether abortion may be characterized as "an appropriate service in connection with pregnancy." Advocates of reproductive rights may argue that it is unequivocally a service "in connection with" pregnancy, namely, the termination thereof. Opponents may counter that the provision ought to be construed in its broader context, which promotes safe and healthy deliveries. Another issue that must be tackled at the national and subnational levels is what threshold of socioeconomic status warrants access to free services.

The Protocol complements CEDAW by empowering individuals (or organizations on their behalf) to raise claims before the Committee alleging treaty violations. ${ }^{3}$ It also grants the Committee sole jurisdiction to review claims and issue recommendations. ${ }^{4}$ States parties have six months to reply and demonstrate actions taken in accordance therewith. ${ }^{5}$ The Committee may also impose interim measures to avoid irreparable harm, the exhaustion of domestic remedies notwithstanding. ${ }^{6}$ For conditions and attendant circumstances (e.g., pregnancy, domestic violence), the timeframe is necessary to ameliorate existent harms or threats to the author's health, life, or safety.

The Committee's Rules of Procedure complement the substantive and procedural safeguards of CEDAW and the Protocol. The deliberative process is enhanced and the objectivity is reaffirmed by procuring testimony from international agencies and organizations with expertise in women's issues. ${ }^{7}$ Specialized agencies (World Health Organization), intergovernmental organizations and UN bodies (e.g., UN Commission on the Status of Women), and nongovernmental organizations (e.g., Population Council) are all examples of potential entities that may contextualize individual claims to facilitate determination of whether states parties are upholding their treaty obligations.

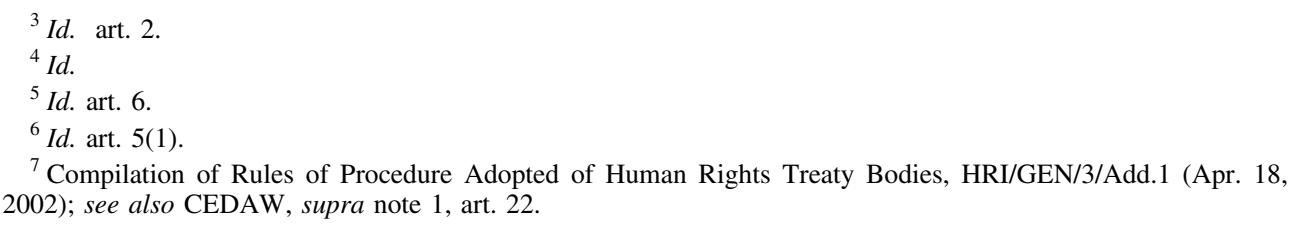




\title{
Interpretive Trends and Proposed Framework for Analysis
}

Although the normative framework does not include an explicit methodology for treaty interpretation, inconsistency and failure to thoroughly examine the relevant legal issues vitiate the deliberative process and compromise the integrity of the outcomes. In at least five instances, the Committee did not address the issue of potential irreparable harm to the aggrieved party. Also, the Committee often relied on its general recommendations as authority for its analysis on the merits. Such recommendations do not enjoy the status of binding legal authority under CEDAW or the Protocol. Moreover, in only one decision was expert guidance alluded to, and even then, the reference appeared in the conclusion rather than the analysis. While existent guidelines may mutually reinforce the Committee's decisions, vague citation in the concluding remarks is neither helpful nor legally sound. Citation of non-binding authority should buttress analysis of legally binding norms and explicit obligations. These brief examples illustrate the challenges of creating objective analyses, in the absence of which, governments would be understandably hesitant to ratify either instrument. My proffered recommendations include a five-step interpretive framework that facilitates admissibility of claims and consideration on the merits. ${ }^{8}$ By undertaking a more robust analysis, the Committee may fully utilize the normative framework to secure women's health.

\section{Follow the Money?: Does the International Fight Against Money Laundering Provide a Model for International Anti-Trafficking Efforts?}

\author{
By Karen E. Bravo*
}

\section{Introduction: Two Crimes; Two Reactions}

Trafficking in human beings, characterized as "'modern day slavery," is a global problem. According to the U.S. State Department's 2008 Trafficking in Persons (TIP) Report, 170 countries have significant trafficking problems and are countries of destination, origin, and/ or transit. Through money laundering, the proceeds derived from a multiplicity of criminal activities are integrated into international or domestic financial and banking sectors so that perpetrators may enjoy illegal profits within the legitimate economy.

The two activities share several characteristics, and both have been criminalized domestically and internationally. Each may take place solely within the domestic sphere of individual nations or territories, but each often exploits interstices in domestic and international law in order to access transnational and transborder markets. They are also linked at two stages of their operation: the availability and use of money laundering is linked to the causes of human trafficking; and, like profiteers from other predicate crimes, the trafficker in human beings uses money laundering services to move proceeds and profits into the legitimate economy.

\section{Anti-Human TrafFicking}

In 2000, the United Nations Convention Against Transnational Organized Crime and the Protocol to Prevent, Suppress and Punish Trafficking in Persons, Especially Women and

\footnotetext{
${ }^{8}$ Dhrubajyoti Bhattacharya, The Perils of Simultaneous Adjudication and Consultation: Using the Optional Protocol to CEDAW to Secure Women's Health, WoMEN's Rights L. REP. _ (2009) (forthcoming).

* Associate Professor of Law, Indiana University School of Law-Indianapolis. This essay is excerpted from an article of the same name forthcoming in Summer 2009 in the University of St. Thomas Law Review.
} 